\title{
AS GRIÔS NO BRASIL: SABERES E FAZERES DE MULHERES NEGRAS ATRAVÉS DA CATEGORIA TIA
}

\author{
Angélica Ferrarez de Almeida ${ }^{1}$ \\ DOI 10.26512/revistacalundu.v4i2.34965
}

\begin{abstract}
Resumo
Através da preservação da memória genealógica, traduzida em saberes e fazeres que constituem as chamadas Tias, vamos refletir como se deu a construção desta categoria política e como a aproximação com o ofício dos griôs da África Ocidental nos proporciona uma linha de entendimento da importância da trajetória destas mulheres negras, por ora, inviabilizadas na história. Logo, a reflexão dos regimes de visibilidade, protagonismo e emancipação, desenvolvida por mulheres negras na dimensão política, cultural e de organização dos espaços da memória em países de reminiscências coloniais, como é o caso do Brasil, nos possibilita inscrever a categoria Tia como um ofício na história social das mulheres. Refletindo assim sua intervenção no mundo a partir do trabalho protagonizado às margens, acionando assim a potência das histórias múltiplas na partilha do comum. Deste modo, vamos nos servir de uma costura bibliográfica enquanto elaboramos e pesquisamos nossas próprias fontes, já que o registro de tais memórias se encontra soterrado nas amarras do pacto colonial. Dito isto, este é um trabalho por regimes de visibilidade e ajuste de memórias.
\end{abstract}

Palavras-chave: Tias. Griôs. Memórias. Saberes. Visibilidades.

\section{GRIOTS EN BRASIL: CONOCIMIENTO Y HACER DE MUJERES NEGRAS A TRAVÉS DE LA CATEGORÍA TIA}

\section{Resumen}

A través de la preservación de la memoria genealógica, traducida en saberes y prácticas que constituyen las llamadas Tias, reflexionaremos sobre cómo se dio la construcción de esta categoría política y cómo la aproximación con la arte de griots de África Occidental, nos proporciona una línea de comprensión de la importancia de la trayectoria de estas mujeres negras, por ahora, inviabilizada en la historia. Por tanto, el reflejo de los regímenes de visibilidad, protagonismo y emancipación, desarrollados por las mujeres negras en la dimensión política, cultural y organizativa de los espacios de memoria en países con reminiscencias coloniales, como es el caso de Brasil, permite inscribir la categoría de Tia como un oficio en la historia social de las mujeres. Reflejando así, su intervención en el mundo desde el trabajo realizado en los márgenes, activando así el poder de las múltiples historias en compartir lo común. De esta manera, utilizaremos una costura bibliográfica mientras elaboramos e investigamos nuestras

\footnotetext{
${ }^{1}$ Doutoranda em História pela UERJ com projeto Mulheres Negras no Pós Abolição: memória, linguagem e poder no ofício da porta bandeira tia Dodô da Portela. Possui mestrado em História Social da Cultura pela Pontifícia Universidade Católica do Rio de Janeiro com tema As tias pretas do samba: por uma questão de memória, espaço e patrimônio. Email: angelferrarez@ gmail.com
} 
propias fuentes, ya que el registro de tales memorias está enterrado en los lazos del pacto colonial. Dicho esto, este es un trabajo para regímenes de visibilidad y ajuste de memorias.

Palabras clave: Tias. Griots. Memorias. Conocimiento. Visibilidades.

\section{No rastro dos griôs}

Eu sou um "griot", antes de qualquer coisa, e o "griot" é a memória do continente africano. Da parte da África do Oeste é a biblioteca e é, também, o guardião das tradições e dos costumes, encarregado da organização de todas as cerimônias. Ninguém se torna "griot". Nasce-se "griot". É de pai para filho. Mas há também as "griotes", as mulheres. São muito poderosas. Quando elas estão, os homens se calam².

Sotigui Kuyaté ${ }^{3}$

O termo francês "griot" apareceu pela primeira vez em francês na obra de Alexis de Saint Lô: Voyage au Sénégal de 1637. Sendo uma das instituições mais antigas da África Ocidental, há relatos de viajantes árabes datados de 1350 sobre a corte do Mali nos quais se descrevem a presença de músicos intérpretes com características bem semelhantes aos "griots", mas que eram conhecidos entre si pelo termo jeli. (BARRY, 2000).

Sendo um estrangeirismo francês, a utilização da palavra "griot", ao mesmo tempo que foi fruto do olhar europeu sobre um ofício mais antigo na África Ocidental, é também uma apropriação por parte dos africanos de uma terminologia que eles souberam bem incorporar enquanto categoria política de existência e (re) existência no mundo. Como não há correspondência no português para esta expressão, vamos adotar a forma aportuguesada griô, como há grafado na Epopeia Mandinga de Sundjata de 1982, romance publicado em diversas versões por Niane Djibril Tamsir, no qual retrata a formação da identidade griô sendo cunhada nas fronteiras, no contato com o olhar classificatório do colonizador, transitando entre o processo de assimilação engendrado pelo europeu e a apropriação por parte do próprio grupo africano.

\footnotetext{
${ }^{2}$ Livre transcrição do documentário: "Sotigui Kouyaté: um griot no Brasil", produzido pelo grupo SESC TV em dezembro de 2006.

${ }^{3}$ Sotigui Kuyaté nasceu no Mali em 1936 e faleceu em Paris em 2010, sendo considerado um dos griôs da contemporaneidade. Seu reconhecimento internacional se deu por conta de seu trabalho no cinema e no teatro, tendo atuado em diversas produções francesas, inclusive com Bernardo Bertolucci e Peter Brook.
} 
A casta dos griôs é uma reminiscência da África Ocidental anterior às formas de comunicação tidas como modernas. É uma casta de contadores de história que, calcados na oralidade e na memória coletiva e genealógica de seu grupo, bem como de seu papel social, são os cronistas sociais e políticos de seu povo, enquanto transmissores de saberes, mantenedores de segredos específicos e produtor semântico responsável por uma espécie de literatura oral calcada no poder da narrativa.

Países como Senegal, Mali, Burkina Faso, Mauritânia, Norte da Costa do Marfim e partes da Nigéria tiveram os griôs na constituição oficial destes países. Ocupando ofício de memorialistas, eles eram os velhos narradores que se serviam das estruturas narrativas a fim de fazer lembrar àquilo que não se deve esquecer. Há uma relação de causa e efeito entre os griôs e a memória e como a causa não é um antes primordial, ela é apenas um dos elementos da dupla (TODOROV, 1970), a memória está para os griôs, assim como estes a edificam. Sua influência, articulada aos domínios da política, foi basilar para o processo de emancipação de várias ex-colônias africanas. A partir destas reflexões nossa atenção se volta para este lugar da memória, da palavra, da narrativa, do dito e o não dito; como um campo epistemológico de saberes e fazeres que atravessaram o oceano e foram fundamentais para a constituição da cultura negra na diáspora. E, neste movimento, a atuação das mulheres foi singular a partir das chamadas Tias do samba, como veremos mais adiante.

Abrindo o diálogo com Hall (2013), o autor aponta três argumentos para o entendimento do que seria essa cultura negra na perspectiva diaspórica. Primeiro, o estilo de manifestações de matriz negra, que os críticos acreditam ser uma casca, um invólucro, acabou por se tornar a matéria do próprio acontecimento, sendo assim a forma dominante da cultura global. Ao mesmo tempo em que é o espaço da experiência dos negros, é o espaço em que o controle de narrativas e representações é deslocado das mãos dos produtores para burocracias culturais estabelecidas. Segundo, com deslocamento do mundo logocêntrico, o domínio da escrita passa para a crítica da escrita e em seguida para seu processo mesmo de desconstrução, movimento que vem acompanhado pelas formas de entendimento a partir de outras bases epistemológicas e nisto a estrutura profunda da vida cultural se abre para a música. E por fim, a abertura para a dimensão do corpo como em telas de representação, como se ele fosse o único capital dos sujeitos negros: 
Considerando a importância atribuída à música no habitus dos negros da diáspora, é irônico que nenhum dos polos neste tenso diálogo leve a música muito a sério. $\mathrm{O}$ narcisismo que une ambos os pontos de vista é revelado pelo modo com que ambos abandonam a discussão da música e da dramaturgia, a performance, o ritual e os gestos que a acompanham em favor de um fascínio obsessivo com os corpos dos próprios artistas. (GILROY, 2012, p. 207)

Chamando atenção para o apelo que a produção cultural da diferença fez a partir dos corpos dos sujeitos negros, Gilroy aponta o estilo, a música e a performance dos corpos como repertórios da cultura negra ou espaços performativos mais latentes para as estratégias dialógicas e as formas híbridas essenciais à estética diaspórica. Se refletirmos a dimensão do som no pós-Abolição, vemos que a música, que encontra seu nascedouro nas dimensões das sociabilidades negras, teve um alcance muito maior que os corpos negros. Aliás, a música dos sujeitos negros adentra espaços em que seus corpos são interditados. Os sons produzidos pelas comunidades negras constituem a paisagem sonora e por isto foram responsáveis pela organização das cidades, do trabalho, da vida rural, das associações negras, dos próprios territórios musicais, vide as escolas de samba no Rio de Janeiro, por exemplo. A partir do reflexo da agência negra nas políticas de emancipação e luta de mulheres, temos no território do samba um campo privilegiado de análise que aponta para a construção da categoria Tia.

São esses dispositivos culturais de origem negra no desenvolvimento de novas epistemologias que junto ao fim de um império cognitivo - parafraseando Souza Santos (2010) ao assinalar o desmonte epistemológico e político do pensamento ocidental auxiliam na audição das insurgentes vozes femininas na atualidade. Não basta apenas a constatação da crise de paradigmas do pensamento hegemônico, há que se ouvir nos espaços de dialogia as diferentes vozes dos sujeitos sociais. Como estamos olhando sobre os ombros de mulheres negras, suas vozes emergem à força da ação política das Tias, as nossas griôs do samba.

\section{Enunciados do (In) visível: nas frestas de uma categoria de análise}

Minha avó foi uma dessas mulheres baianas que mudaram a forma de pensar e de agir do povo escravo que veio para o Brasil em navios negreiros e, após a Lei do Ventre Livre e a própria Lei Áurea, manteve suas tradições, seus deuses e seus costumes em nosso país. (SILVA, 2009, p. 17). 
Com estas palavras Yara da Silva abre seu livro: Tia Carmem: negra tradição da Praça Onze sobre sua avó Tia Carmem do Xibuca. Sendo um dos poucos registros escritos sobre as Tias, a autora faz deste uma singela homenagem e exercício afetivo de resgate de uma determinada memória. Carmem Teixeira da Conceição proveniente de Amaralina, Salvador, Bahia, nasceu em 1878 e foi para o Rio de Janeiro em 1893 indo morar na rua Senador Pompeu, Zona Portuária. Recebeu o apelido do marido, Xibuca, após casar-se com Manoel Teixeira com quem teve 22 filhos. Filha do Orixá feminino Oxum ela era rezadeira, quituteira, vendia seus doces no tabuleiro na Lapa, Campo de Santana e Praça Tiradentes. Relatam-na como uma mulher muito festeira que saía em vários ranchos carnavalescos e frequentava os quintais das casas das amigas, Tia Ciata e Tia Bebiana.

As Tias, que serão grafadas aqui em maiúsculo para não perdermos na dimensão desta categoria de análise, a perspectiva do ofício, são, em sua maioria, mulheres mais velhas, detentoras de um saber fazer que remonta uma memória genealógica de herança africana na cidade do Rio de Janeiro. Existe no ser Tia algo de poder e de político, que faz com que elas sejam legítimas ao ponto de: "mudar a forma de pensar e de agir do povo escravo que veio para o Brasil em navios negreiros...”, como nos aponta Silva acima. Progenitoras, líderes, rezadeiras, cozinheiras, sambistas, quituteiras, quitandeiras, organizadas, conscientizadas, mães de santo; estas Tias manipulam tantos códigos que chegam a concorrer com outras formas de organização das famílias, da cidade e da cultura. Responsáveis pela primeira geração de sambistas, já que foram as mães destes, elas eram as chefas de famílias extensas e muitas frentes familiares se formavam a partir do crivo de uma Tia e da existência de seu quintal.

A dimensão histórica dos quintais cumpre papel importante para a compreensão, pois território e cultura se articulam de maneiras diversas e geram representações e valores em tempos históricos diferentes. Praças, terreiros, quintais foram centros culturais, sinalizando uma dimensão do espaço que serviu às manifestações da cultura negra. Logo, podemos vislumbrar o quintal das casas das tias e a reunião destes quintais culminando numa cartografia negra das cidades.

Com relação à família, não se pode pensá-la como um fato universal e natural, mas como sistema organizador de ideias, valores e aspirações. $\mathrm{Na}$ ordem colonial burguesa, por exemplo, costuma-se fazer uma certa distinção entre família, propriamente dita, e, parentesco. Os termos não significam exatamente a mesma coisa, e assim predomina a visão institucional que delimita a família nuclear e a família mais 
extensa em função dos laços consanguíneos. Entretanto, saindo do epicentro colonial ocidental, vemos que as sociabilidades entre negros na diáspora nos ofertou uma outra dimensão de família baseada em estratégias de solidariedade étnica e religiosa (SLENES, 1999; REIS, 1987). Daí a defesa de que estas Tias são responsáveis pela manutenção de grandes famílias extensas, que se reúnem em seus quintais, tanto para a manifestação da música, quanto para a dimensão do sagrado.

Fazendo algumas considerações acerca de Tia Ciata através da obra Macunaíma de Mário de Andrade, este nos chama atenção para o capítulo intitulado: "Macumba". Conta a história de quando Macunaíma, a fim de se vingar de Venceslau Pietro Pietra, recorre ao poder dos feitiços dos negros pedindo auxílio ao Orixá Exu. Mesmo sendo uma obra de ficção, é interessante observar o poder desta Tia através do cenário montado por Andrade:

Era junho e o tempo estava inteiramente frio. A macumba se rezava lá no Mangue, no zungu de Tia Ciata, feiticeira como não tinha outra, mãe de santo famanada e cantadeira ao violão. Ás vinte horas Macunaíma chegou na biboca levando debaixo do braço o garrafão de pinga obrigatório. Já tinha muita gente lá, gente direita, gente pobre, advogados garçons pedreiros meias-colheres deputados gatunos, todas essas gentes e a função ia principiando. Macunaíma tirou os sapatos e as meias como os outros e enfiou no pescoço a milonga feita de cera de vespa tatucaba e raiz seca de açacu. Entrou na sala cheia e afastando a mosquitada foi de quatro saudar a camdomblezeira imóvel sentada na tripeça, não falando um isto. Tia Ciata era uma negra velha com um século no sofrimento, javevó e galguincha com a cabeleira branca esparramada feito luz em torno da cabeça pequetita. Ninguém mais não enxergava olhos nela, era só ossos duma compridez já sonolente pendendo pro chão da terra. (ANDRADE, 2008, pp.75/76).

Hilária Batista de Almeida, ou simplesmente Tia Ciata, era filha do Orixá Oxum, mãe pequena no terreiro do famoso pai de santo João Alabá ${ }^{4}$, o mesmo frequentado por tia Carmem e outras tias. Nasceu em 1854, em Santo Amaro da Purificação, Recôncavo Baiano, mudando-se para o Rio de janeiro em 1876 com 22 anos. Do relato acima podemos depreender algumas características interessantes: "candomblezeira", "feiticeira", "mãe de santo", "cantadeira ao violão", "negra velha", "cabeleira branca", mas a que salta aos olhos é a rede de pessoas em torno dela, que precisam de suas rezas, feitiços ou "macumba". Uma rede heterogênea “... gente direita, gente pobre,

\footnotetext{
${ }^{4}$ Fundado em 1886, este é considerado um dos primeiros terreiros de candomblé na cidade do rio de Janeiro, no bairro da Saúde na Zona Portuária.
} 
advogados, garçons, pedreiros, meias colheres, deputados, gatunos, todas essas gentes...". Importante a imagem da Tia como centralizadora das relações, onde as diferenças eram minimizadas em prol de uma imagem quase sacralizada pelos assistidos, a ponto do próprio Macunaíma ir "de quatro saudar a camdomblezeira imóvel sentada na tripeça, não falando um isto".

A casa de Tia Ciata, na Praça Onze no Rio de Janeiro, foi um polo irradiador da cultura negra carioca com suas primeiras reuniões de samba. As festas ali aconteciam no quintal onde se faziam também os rituais dos orixás, seguida da cerimônia religiosa, frequentemente antecedida pela missa cristã, assistida na igreja (SILVA, 2009). Interessante essa noção da missa antes das celebrações nos quintais das Tias, a própria Tia Carmem, antes de armar a festa no quintal de casa, assistia missa na Igreja de São Jorge. Este lado festivo das Tias é narrado em vários tipos de literatura e suas festas tinham este ar sincretizado. Festas que começam na igreja e terminam com as rodas de pagode e batuques.

É importante observar a interface com a dimensão da festa, pois diferente das correntes que pensam a festa enquanto distração das massas, estratégia das classes dominantes a fim de manipular o povo, antagônica ao trabalho, sendo basilar para a construção dicotômica da razão instrumental X ritual, bem como da razão produtiva $X$ capitalista; a festa aqui é política.

\footnotetext{
Queremos chamar atenção para o fato de que o domínio sobre as grandes festas populares como o Carnaval, parece ter sido tão premente e importante para o controle e desenvolvimento da cidade quanto o era a adoção de ferrovias, planos urbanísticos, posturas municipais, medidas de higiene e etc., o que nos leva a concluir que, como sempre, desde o princípio, as transformações urbanas não se resumem à sua materialidade mas também às suas dimensões imateriais e do imaginário. (FERNANDES, 2001, p. 15)
}

Assim, a festa protagonizada por negros se impõe restituindo-os poder, cidadania e humanidades roubadas. É claro que as festas, em geral, têm o poder de transcendência, introduzem outra dimensão de tempo e lugar, têm capacidade de revolver o ser humano e, neste sentido, não queremos perder a dimensão lúdica da festa, mas sim chamar atenção para a festa como lugar, por excelência, da crítica social e que coloca o princípio do "panis et circense", o famoso pão e circo em cheque. As festas do quintal das Tias foram momentos onde sujeitas e sujeitos negros se viram protagonizando e performando a cultura urbana de herança diaspórica. 
Diz Tia Carmem do Xibuca: “A nossa casa era o ponto de encontro de todo mundo que gostava de um pagode. O João da Baiana, por exemplo, só queria sambar e tocar pandeiro (...), não sei como o João foi parar no rádio" (SILVA, 2009, p. 111). Interessante a afirmativa acima porque demonstra que a familiaridade com estes primeiros sambistas chegou ao ponto de não perceberem a projeção dos mesmos fora do reduto dos quintais. E continua Silva: “Os sambistas também se reuniam na casa da vovó, mas na época, ela dizia, que não havia o chamado tratamento de sambista: eram apenas pessoas que cumpriam os rituais africanos e a coisa terminava em samba" (Ibid, p. 80).

Segundo Michel Mafesoli é no imbricamento entre indivíduo, cultura e território que deve ser buscado o fundamento para o apego afetivo, ou "enraizamento dinâmico" (MAFESOLI, 1984, p. 13). As Tias acabam por formar uma rede familiar em torno delas, no espaço da casa, nos usos festivo e religioso do quintal, no domínio sobre a alimentação, nas recordações que eram ali ouvidas, afinal, ir ao encontro destas Tias, que estavam impulsionando a cultura urbana e criando espaço para o desenvolvimento do que seria uma cultura negra, é ir ao encontro das lembranças que animam este universo.

O espaço privilegiado para as festas das Tias era o quintal, geralmente, nos fundos da casa. Pensando nos discursos de subalternização, vemos que coube ao quintal a tarefa de abrigar os eventos tidos como mais subalternos para a ascendente sociedade burguesa e não à toa que este ficava nos fundos, diferente dos quintais da família burguesa que ficavam na frente de casa. Lembrando que dentro da estrutura da casa, o quintal, muitas vezes, tem que ser camuflado para que seus eventos não sejam interrompidos pela repressão. Ao mesmo tempo, seu chão de "terra batida", uma imagem que remete ao elemento terra tendo o terreiro enquanto continuação possível de valores ancestrais, não sem mais que é no quintal de "terra batida" que ficavam "ritualmente dispostas às coisas do culto" de matriz africana. Essa religiosidade, camuflada para que viva, foi estrategicamente pensada pelas Tias (ALMEIDA, 2013).

Celeiro de grandes encontros era também o quintal de Tia Amélia do Aragão, que ganhou o Aragão no nome porque morava na rua do Aragão. Cantadora de modinha e mãe do cantor e compositor Donga. Havia as rezadeiras, Tia Bebiana e Tia Perciliana, esta última mãe do sambista João da Baiana que, unidas a Tia Ciata, Tia Carmem e outras, pertenciam todas ao terreiro de candomblé de João Alabá. Havia a grande 
quituteira Tia Veridiana, e, também Tia Sadata da Pedra do Sal, que foi fundadora do rancho carnavalesco Rei de Ouro.

Interessante que as Tias mencionadas até agora eram todas baianas e moradoras da Zona Portuária de finais do século XIX. Contudo, não vamos repetir, sem problematizar, a ideia de uma centralidade baiana. Aliás, a incipiente bibliografia sobre elas cunhou no imaginário social a ideia de uma diáspora baiana que carece de estudos mais aprofundados, interesse que vem se desdobrando em futuras pesquisas sobre a Bahia oitocentista, mas, por ora, vamos tentar descobrir o que este mito encobre ao descentralizar a influência baiana, a fim de ampliar os espaços políticos e territoriais da "pequena África".

\section{Nem tão baianas assim: sobre trânsitos e deslocamentos}

Proponho que a espacialidade das Tias não seja lida entre baías - Baía de Todos os Santos e Baía da Guanabara - representando Salvador e Rio de Janeiro respectivamente, e, para tanto compartilho com o historiador Tiago de Melo Gomes (2003) ao apontar a importância dos deslocamentos de mineiros e fluminenses para a cidade do Rio de finais do século XIX. Em vez de colaborar com uma historiografia do isolacionismo, pensando em grupos separados, queremos ampliar o debate, refletindo o trânsito e experiência das Tias para além da centralidade baiana e da Zona Portuária.

[...] entre 1872 e 1890 a Bahia perdeu apenas sete mil habitantes através da migração interprovincial. Na última década do século XIX, o mesmo estado teve um saldo positivo de 40 mil pessoas no quadro nacional das migrações, tornando-se um fornecedor de migrantes internos apenas a partir de $1900 \mathrm{e}$ nos vinte anos seguintes, quando perde por esta via 116 mil habitantes. Não se pode, contudo, postular que a maioria destes migrantes tenha se dirigido à Capital, pois esta recebeu apenas 55 mil novos migrantes internos no mesmo período (menos que Pará e Pernambuco e pouco mais que o Rio Grande do Sul). Por certo, uma parte significativa destes novos habitantes da Capital era composta por mineiros, já que o estado de Minas Gerais cedeu 220 mil pessoas a outras unidades da federação no mesmo período. (GOMES, 2003, p. 7)

Tia Eulália, por exemplo, era mineira, chegando ao Rio de Janeiro foi para a comunidade da Serrinha em Madureira por volta da década de 30. Outra que chega à mesma época é Vó Maria do Jongo, proveniente do interior do Estado do Rio. Reduto 
do jongo ${ }^{5}$, a região de Madureira entrou fortemente no circuito das artes negras da cidade, vindo abrigar as escolas de samba Império Serrano, de 1947, e a Portela de $1923^{6}$, ambas fundadas por Tias não baianas, além de Mano Décio, Mano Elói, Seu Alfredo e Mestre Fuleiro, sendo o primeiro o único baiano da turma do Império. Além de Paulo da Portela, Antônio Rufino e Antônio Caetano, o triunvirato carioca da Portela.

Transitando pela cidade e chegando ao Morro do Salgueiro, a grande referência era a Tia Neném, nascida ali mesmo em 1921. A Tia Zezé, nascida em Três Rios em 1923, foi componente importante da Unidos da Tijuca e tantas outras Tias provenientes de vários lugares e contribuindo com a descentralização do mito de uma diáspora baiana. Óbvio que as Tias provenientes da Bahia foram marcantes sim na cultura urbana carioca, introduzindo modos de vestir, de saberes e pensar, mas em sua maioria migraram durante meados do século XIX, provavelmente como escravizadas, acompanhando as famílias para as quais trabalhavam e muitas colocadas ao ganho ${ }^{7}$.

Olívia Cunha assim nos diz:

Responsáveis pela mediação dos ambientes domésticos e públicos, as mulheres livres e escravas dominavam o mercado de trabalho, por transpor com mais permissividade as fronteiras da intimidade da família patriarcal, ganhando as ruas. Ao contrário dos homens, as criadas eram vistas como mais afeitas à aparente leveza das tarefas do lar e supostamente mais inofensivas aos segredos familiares. ... Mesmo considerando a precária estrutura das habitações da Corte na segunda metade do século XIX, o que contribuía para que os serviços realizados dentro de cassa fossem tão ou mais pesados do que aqueles realizados fora, as construções da domesticidade atreladas a certa concepção do trabalho feminino foram culturalmente dominantes. (Cunha, 2007, p. 380).

\footnotetext{
${ }^{5}$ Dança afrobrasileira de caráter mítico religioso, originária talvez da região de Benguela, atual Angola, que se desenvolveu na região sudeste do país e tem no Rio as baluartes Vó Maria do jongo e a própria tia Eulália, ambas da Serrinha.

${ }^{6}$ O Grêmio Recreativo Escola de Samba Portela, ou simplesmente Portela, é uma escola de samba fundada em Madureira no ano de 1923. Inicialmente ela foi fundada numa dissidência entre dois blocos carnavalescos, o "Baianinhas de Oswaldo Cruz", cujos diretores eram Paulo da Portela, Heitor dos Prazeres, Antônio Caetano, Manuel Bam Bam Bam, Natalino José do Nascimento, o famoso Seu Natal, dentre outros, e o "Quem fala de nós come mosca" cuja origem remete ao famoso quintal de Tia Esther. Dessa dissidência Paulo da Portela liderou o grupo que formou o "Conjunto Oswaldo Cruz", que foi renomeado para: "Quem nos faz é o capricho", e depois: "Vai Como Pode", nome que a escola teve até 1935, ano de seu primeiro título quando assume o nome Portela.

${ }^{7}$ Faceta da escravidão urbana em que escravizadas e escravizados eram liberados do trabalho doméstico para comerciar nas ruas da cidade, entretanto, sem, contudo, perderem o vínculo de servidão com seus donos, os quais recebiam uma boa quantia deste ganho, cláusula.
} 
Deste modo, vemos que há uma associação culturalmente construída entre domesticidade, família e feminilidade, onde as mulheres sempre foram tidas como melhores para os serviços domésticos, entretanto questões de ordem econômica faz com que muitos senhores e senhoras coloquem seus escravos ao ganho, constituindo nisto mais uma forma de negócio da empresa escravista. Contudo, estar nas ruas é que garantiu mais mobilidade, formação de redes e de canais de comunicação. Como diz o cronista João do Rio: "Sem o consentimento das ruas não passam os sábios...” (2010, p. 52). No que emendamos: e nem se forma a cartografia dos quintais, movimento mais peculiar no pós-Abolição; portanto, os trânsitos e deslocamentos de mulheres negras ficam mais acirrados durante a primeira metade do século $\mathrm{XX}$, e neste momento as migrações, por exemplo, do Vale do Café ${ }^{8}$ para o Rio de Janeiro, são muito mais intensas (COSTA, 2015). É deste período a mudança da futura porta-bandeira da Portela, Tia Dodô, de Barra Mansa para o centro do Rio, assim como fez a família da cantora Clementina de Jesus anos antes, só que saindo de Valença e se estabelecendo na pacata e ainda região rural Freguesia de Jacarepaguá.

Em Memórias do Cativeiro, Rios (2005), analisando os deslocamentos a partir do Vale do Café, indicou em suas pesquisas que não foi logo após a abolição que as migrações para a capital ocorreram. A relação com a terra ainda era pulsante e existiam certos traços estáveis quando, por exemplo, os proprietários da terra conseguiam manter a mão de obra negra de ex-escravos e libertos através de vínculos de trabalho livre, e não estáveis, quando esse trabalhador vagava entre as fazendas na busca por trabalho temporário. Aliás, a relação com a terra foi um vetor de atração para os espaços ainda rurais das cidades, daí a ocupação dos subúrbios e da Baixada Fluminense no Rio.

Primeiro, a relação com a terra foi catalisadora dos processos migratórios atraindo pessoas para os subúrbios cariocas e à Baixada Fluminense da cidade, onde havia uma nascente economia em torno da laranja e seu mercado agroexportador (ABREU, 1988; PEREIRA, 1977). Segundo, e totalmente correlacionado, a familiaridade com o meio rural encontrada nos subúrbios cariocas acabou atraindo esta mão de obra. Terceiro, com o desenvolvimento das linhas férreas de carga, os produtos saídos da decadente região cafeeira passavam antes em regiões da Baixada Fluminense, antes de descarregar as encomendas no centro da cidade. Quarto, por mais que haja

\footnotetext{
${ }^{8}$ O Vale do Paraíba ou Vale do Café, como é popularmente conhecido, é uma região cortada pelo rio Paraíba do Sul, que abrange quinze municípios do Estado do Rio, e, que teve seu auge na economia cafeeira, bem como na empresa escravocrata, na segunda metade do século XIX.
} 
possibilidade de moradia nos centros urbanos, principalmente através do acionamento de vínculos familiares com pessoas que tinham chegado em levas migrantes anteriores, a possibilidade de obtenção de terras era maior no subúrbio rural do que no centro, onde o trabalho estava concentrado no porto. E, por fim, a mobilidade que a comunidade negra experimentou no pós-Abolição com a instabilidade do período combinada às formas de violência e opressão de suas culturas, impulsionando assim a escolha por espaços nos quais o poder público não dava prioridade de assistência, propiciando, dessa forma, mais brechas para os processos de criação, isto é, espaços para manifestações festivas de cunho cultural e religioso.

Daí vemos florescer a experiência do jongo no subúrbio de Madureira, deslocado das festas e dos batuques dos negros da região cafeeira. A simbologia das rodas e as experiências negro-africanas de origem bantu, já que era desta nação a maioria dos ex-escravizados encontrados na empresa cafeeira que migraram para a cidade na primeira metade do século XX. A partir disso outras centralidades são produzidas onde discursos, imagens e narrativas são deslocados para formar novos lugares de pertença, novos imaginários simbólicos dos sujeitos negros, novas concepções do tempo e da memória e práticas de cotidiano:

Mais ou menos é assim o subúrbio, na sua pobreza e no abandono em que os poderes públicos o deixam. Pelas primeiras horas da manhã, de todas aquelas bibocas, alforjas, trilhos, morros, travessas, grotas, ruas, sai gente, que se encaminha para a estação mais próxima; alguns morando mais longe, em Inhaúma, em Cachambi, em Jacarepaguá, perdem amor e alguns níqueis e tomam bondes que chegam cheios às estações. (BARRETO, 2009, p. 88)

Os casos de Madureira e Osvaldo Cruz são interessantes para pensar a crescente participação do poder público a partir de desenvolvimento local impulsionado pela agência da cultura urbana negra. Estes bairros que pertenciam à Freguesia do Irajá crescem de formas variadas. Madureira se desenvolve com a intensificação do comércio, abrigando, inclusive, o maior mercado de distribuição de produtos para os subúrbios, mercado que surgia como uma feira de rua em 1914 e vai se complexificando e modernizando com o tempo, sendo portugueses, italianos e até alguns brasileiros os donos dos primeiros estabelecimentos (MARTINS, 2009). Já Osvaldo Cruz ganha características mais residenciais, com suas vilas, herança do desmembramento das grandes chácaras de outrora, e, mais tarde, com os conjuntos residenciais. 
A espacialidade desta cidade com suas fronteiras, além de não ser bem definida, estava longe de representar algo homogêneo. À mistura de libertos, os ex-escravizados, com os nascidos livres e os migrantes vindos da Bahia, Minas Gerais, Espírito Santo, além do interior do Rio, se juntaram os imigrantes europeus, eram italianos, espanhóis, portugueses, franceses, ingleses e árabes compondo a paisagem desta cidade. Para além de descentralizar a ideia de uma "diáspora baiana", gostaríamos também de ampliar os limites espaciais e políticos da "pequena África". Expressão cunhada a partir da ideia do sambista Heitor dos Prazeres que, ao observar o fluxo maior de negros nas ruas da cidade, disse estar em "uma África em miniatura", se referindo, sobretudo, à Zona Portuária. Entretanto, quero pensar aqui os símbolos que justificam a defesa da "pequena África" enquanto mito fundacional da vontade de uma civilização africana entre nós para assim ampliar suas fronteiras a fim de costurar a cidade negra.

Imaginemos que chegar à região portuária era como se estivéssemos entrando numa empresa escravocrata, com repartições, hierarquias que obedeciam a postos de trabalho, divisão racional e instrumental, usos diferenciados dos espaços, enfim, tinhase desde o Cais do Valongo ${ }^{9}$, os espaços dos trapiches e pelourinhos, até a Pedra do Sal, o Largo do Depósito, o Cemitério dos Pretos Novos, enfim, todo um complexo que servia à empresa escravocrata. Com o pós-Abolição, essa memória, por vezes, literalmente soterrada, encoberta em relações de poder e violência, emergiu pela agência dos grupos negros quando resgataram a ideia de uma "pequena África", nascida no solo de muito trabalho e sofrimento, mas apoiada nos espaços de vivência e circulação dos negros e na perspectiva de uma consciência histórica. Portanto, é como construção política e vetor de reivindicação de existência e humanidades negadas que ampliamos a ideia da "pequena África" a fim de pensar esta cidade.

A apropriação da "pequena África" enquanto um isolado idílico onde as manifestações negras são tidas como coesas e homogêneas, e a de uma diáspora baiana, como catalizadora para a produção da cultura urbana, foram imagens reproduzidas e muito pouco problematizadas na historiografia (MOURA, 1995). Por isto, a ideia da "pequena África" enquanto construção política de determinados herdeiros é mais interessante e reflexiva. A partir da ideia da herança, Hall (2013) diz que herdeiro é

\footnotetext{
${ }^{9}$ No ano de 2013, o Conselho Científico Internacional da Unesco, através do projeto "Rota do Escravo: resistência, liberdade e herança", fixou uma placa no Cais apontado como lugar de memória da Diáspora Africana nas Américas. No ano seguinte, houve a candidatura do Sítio Arqueológico do Cais do Valongo a patrimônio da humanidade e em 2017, finalmente, houve a declaração do Cais como patrimônio do mundo pela Unesco.
} 
aquele que usa e dissipa a herança a partir de uma ação do presente, ou seja, a relação com o passado se desenrola a partir dos significados e das relações de poder que fizeram com que as coisas viessem à tona. É o acionamento no presente que ativa esse passado no acionamento das disputas.

Os usos comuns desta herança pela comunidade negra fizeram desenvolver, nos espaços desta cidade, várias "pequenas Áfricas" para além da já consagrada região portuária, e foram as Tias do samba e os sambistas transitando pela cidade, a cultura que se desenvolve na relação com as ruas, ou a que estava sendo cultivada nos subúrbios mais rurais ou ainda nos grandes ajuntamentos; todo esse movimento que produz a cultura da cidade edificada no calçamento da herança escravocrata. Neste sentido, a autoridade discursiva das mulheres se faz notória, seja na organização dos espaços da cidade, no plano familiar, na gestão de pequenos negócios, na produção de seus quintais, enfim, uma autoridade que se consolida através das lutas por emancipação e protagonismo da comunidade negra. Pois o que está em jogo na atuação política da Tia é sempre a emancipação de uma comunidade, de uma família, e, portanto, de outras mulheres.

\section{À guisa de conclusão}

$\mathrm{O}$ argumento da memória genealógica, associado a uma herança imaterial, calcada em saberes e fazeres e seu processo de transmissão, através das estruturas narrativas, fez com que aproximássemos o ofício das Tias do samba àquele das griôs da África Ocidental. Fragmentos de um caminho que fizeram uma longa travessia e foram remontados diasporicamente. Um movimento de transmissão no espaço tempo, onde signos e símbolos foram ressignificados e muitos códigos estratégicos de sobrevivência sobreviveram à margem do projeto colonial.

Lendo as margens aqui na perspectiva de Bell Hooks (1989), que a representa não apenas como sinônimo de periferia, mas um espaço mais complexo que por ser tanto um local de repressão quanto de resistência, se apresenta como um "espaço de abertura radical" (Hooks, 1989, p. 149) de possibilidades e criatividade. Lembrando que há uma cilada a ser evitada, o ler a margem como lugar de criatividade que é, justamente, o perigo de romantizar a opressão (KILOMBA, 2019). Logo, este não é um 
exercício romântico, mas o reconhecimento da margem como uma posição complexa na medida em que tangencia mais de um local.

Outro perigo que devemos evitar é o de polarizar a discussão dividida em dois atores coletivos, os poderosos brancos e os fracos negros, cada qual tentando tirar as vantagens possíveis a partir de um racionalismo supostamente universal. Neste sentido, a história que estamos apresentando passa a ter um duplo alcance, já que é a história de vida de mulheres negras e das situações que as levaram a ter uma intervenção no mundo. $\mathrm{O}$ que permite que recordemos e atualizemos experiências que envolvem práticas de luta para tornar visível o trabalho que mulheres empreenderam na organização da cidade. Aqui a quebra visceral está no deslocamento da ideia de "um sujeito universal" e na (re) fundação de experiências "universais", a partir de atores sociais historicamente marginalizados. E aqui o saber das Tias deve ser valorizado, sendo, inclusive, moeda de troca e abertura de diálogo com as instâncias do Estado.

O que está em jogo são projetos de descentralização do poder, na medida em que trajetórias insurgentes de mulheres negras, antes invisibilizadas, se atualizam nestas páginas. É o acionamento da potência das histórias múltiplas na partilha do comum que nos interessa, sobretudo. Através da trajetória das Tias podemos perceber como elas acionaram e acionam "modos de saber e fazer" que formam a contrapartida de um sistema que as exclui, ofertando assim possibilidades. As regras do poder são travadas não só pelas partes envolvidas, mas por outros atores que podem aparecer menos ou mais segundo as circunstâncias e, neste jogo, dominadores e dominados não são uma sentença, mas um papel móvel.

Atualmente, vivemos a falência de um modelo ocidental em que, parafraseando Krenak (2019), estamos buscando ideias para adiar o fim do mundo. A emergência de antídotos alternativos está implodindo o campo dos saberes e da prática política. Está decretada a implosão do suposto "centro" e estamos buscando nas margens, nas bordas formas de vida que nos possibilite respirar. Estamos no rastro das memórias que foram interditadas na história, trazendo à consciência as verdades desagradáveis que, ora, foram jogadas para o nível da inconsciência. Neste movimento, os grupos invisibilizados estão elaborando regimes de visibilidade e, talvez, os saberes e fazeres das Tias cumpram um papel importante neste reposicionamento. 


\section{Referências Bibliográficas}

ABREU, Maurício. Evolução Urbana do Rio de Janeiro. 2ed. Rio de Janeiro: IPLANRIO/Jorge Zahar Ed, 1988.

ALMEIDA, Angélica Ferrarez de. "A tradição das Tias pretas na Zona Portuária: por uma questão de memória, espaço e patrimônio". 2013. Dissertação (Mestrado em História Social da Cultura) - Centro de Ciências Sociais, Pontifícia Universidade Católica do Rio de Janeiro, Rio de Janeiro, 2013.

ANDRADE, Mário de. Macunaíma, o herói sem nenhum caráter. Rio de Janeiro: Agir, 2008.

BARRETO, Lima. Clara dos Anjos. São Paulo: Paulus, 2009.

BARRY, Boubacar. Senegâmbia: o desafio da história regional. Rio de Janeiro: SEPHIS, 2000.

COSTA, Carlos Eduardo Coutinho da. "Migrações negras no pós Abolição do Sudeste Cafeeiro (1888-1940)". Revista Topoi, v. 16, n. 30, jan/jun, 2015.

CUNHA, Olivia Maria Gomes; GOMES, Flávio dos Santos. Quase-Cidadão: histórias e antropologias da pós emancipação no Brasil. Rio de Janeiro: Editora da FGV, 2007.

FERNANDES, Nelson da Nobrega. Escolas de Samba: sujeitos celebrantes e objetos celebrados. Rio de Janeiro: Secretaria das Culturas, Departamento Geral de Documentação e Informação Cultural, Arquivo Geral da Cidade do Rio de Janeiro, 2001.

GILROY, Paul. O Atlântico Negro: modernidade e dupla consciência. Trad. Cid Knipel Moreira. 2 ed. São Paulo/Rio de Janeiro: Editora 34/UCAM, 2012.

GOMES, Tiago de Melo. "Para além da casa da tia Ciata: outras experiências no universo cultural carioca, 1830-1930”. Revista Afro-Ásia, n.29/30, 2003.

HALL, Stuart. Da Diáspora: identidades e mediações culturais. Org. Liv Sovik; Trad. Adelaine La Guardi Resende [et all] 2 ed. Belo Horizonte: Editora da UFMG, 2013.

hooks, bell. Talking Back: thinking feminist, talking black. Boston: South End Press, 1989.

KILOMBA, Grada. Memórias da Plantação: episódios de racismo cotidiano. Trad. Jess Oliveira. Rio de Janeiro: Cobogó, 2019.

KRENAK, Ailton (2019). Ideias Para Adiar o Fim do Mundo. São Paulo: Companhia das Letras, 2019.

MAFESOLI, Michel. A Conquista do Presente. Rio de Janeiro: Rocco, 1984. 
MARTINS, Ronaldo Luiz. Mercadão de Madureira: caminhos do comércio. Rio de Janeiro: Condomínio do Entreposto Mercado do Rio de Janeiro, 2009.

MOURA, Roberto. Tia Ciata e a Pequena África no Rio de Janeiro. Rio de Janeiro: Secretaria Municipal de Cultura, 1995.

NIANE, Djibril Tamsir. Sundjata ou a Epopeia Mandinga. Trad. Oswaldo Biato. São Paulo: Ática, 1982.

PEREIRA, W. Cana, Café e Laranja: história econômica de Nova Iguaçu. Rio de Janeiro: Ed. FGV, 1977.

REIS, João José. Rebelião Escrava no Brasil: a história do levante dos Malês (1835). São Paulo: Brasiliense, 1987.

RIO, João do. A Alma Encantadora das Ruas. Rio de Janeiro: Cidade Viva, 2010.

RIOS, Ana Lugão; MATTOS, Hebe. Memórias do Cativeiro: família, trabalho e cidadania no pós-abolição. Rio de Janeiro: Civilização Brasileira, 2005.

SANTOS, Boaventura de Souza; MENESES, Maria Paula (orgs). Epistemologias do Sul. Coimbra: Almedina, 2010.

SESC TV. Sotigui Kuyaté: um griô no Brasil. Documentário. Dezembro, 2006.

SILVA, Yara da. Tia Carmem: negra tradição da Praça Onze. Rio de Janeiro: Garamond, 2009.

SLENES, Robert W. Na Senzala, uma Flor: esperanças e recordações na formação da família escrava. Rio de Janeiro: Nova fronteira, 1999.

TODOROV, Tzevetan. As Estruturas Narrativas. São Paulo: Perspectiva, 1970.

Recebido em: 01/11/2020

Aceito em: 01/11/2020 